\title{
ECONOMICS
}

\section{Method of integrated risk managements for agroindustrial progects}

\author{
O. Denchyk ${ }^{1}$, K. Krol ${ }^{2}$ \\ University "KROK”, Kyiv, Ukraine \\ Corresponding author. E-mail: ${ }^{1}$ oksanadenchyk@gmail.com, ${ }^{2}$ krolkonrad61@gmail.com
}

Paper received 28.08.19; Accepted for publication 12.09.19.

https://doi.org/10.31174/SEND-HS2019-205VII34-06

\begin{abstract}
This study presents a method and describes algorithms of the integrated risk management of agroidustrial projects that have been developed based on the performed convergence of the risk management processes, risk management methodologies and project management standards PMI (PMBoK), PRINCE2, P2M, IPMA (ICB), AGILE. Application of the described method will enable to save time of the project manager when selecting the project risk working tools and reduce the overall risk of the project, thereby advancing efficiency of the project management as a whole.
\end{abstract}

Keywords: projects, risk management, method, risk management methods, agroindustrial projects.

Introduction. The problem of growing world population and resource constraints requires scientists from all over the world to work on creating mechanisms to provide humanity, first and foremost, with high-quality and diverse food products. Responsible consumption in combination with increased production of livestock and plant production will help to solve this problem. In this context, the issue of increasing the size and success of projects of agro-industrial complex becomes extremely important. Risk management has a significant impact on the progress and success of the project. In agricultural projects, along with the usual risk factors, there are specific sectoral risks [1]. Providing farmers with convenient and understandable risk management tools will help not only to reduce losses from the risk situation, but also to take advantage of opportunities and to increase food production in a timely manner.

Review of publications on the topic. Domestic and foreign scientists have made a significant contribution to risk management.

Kobylyanska O. M. [2] devoted her scientific work to study the impact of industrial risks on the activities of agricultural enterprises. Scientists Nguyen N., Wegener M., Russell I., Cameron D., Coventry D. and Cooper I. [3] emphasized that agricultural projects related to agriculture have a specific primary source of risk - uncertainty of weather from which derivatives are financial risks, government policy and marketing risks.

Kahan D. [4] drew attention to such risk sources as pests and diseases related to agro-industrial projects specializing in production of products for both livestock and crop production.

Scientists Hurduzeu G., Huidumac C., Hurduzeu R. [5] introduce the term risk culture and emphasize the importance of understanding farmers' sources and manifestations of risks and the need to find ways to manage risks that have a significant impact on the profit of agricultural enterprises.

In project management, the most common approaches to risk management include the use of risk management methodologies for project management standards.

The risk management processes in the various project management methodologies (PMBoK) [6], PRINCE2 [7], P2M [8], IPMA (ICB) [9], AGILE [10]) have a number of common features that are not only relevant to the approach to define the concept of risk, but also the basic processes of risk management to ensure the completeness and efficiency of their management. In the work [11] Danchenko O. B. sees a generalization of the world's experience and integration of existing approaches and techniques into one process of risk management as further development of the risk management methodology.

Studies of project management methodologies show, on the one hand, that each of the existing methodologies has methodological gaps and internal conflicts; on the other hand, practical business requires a systematic integrated approach that ensures continuity of all elements of project management in their harmonious, self-consistent interaction [12].

Bushuyev S. D., Bushuyeva N. S., Nyeizvyestnyi S. I. proposed convergence of project management methodologies considered in the paper [13].

Convergence of risk management processes was conducted on the basis of the analysis of risk management processes in the management methodologies, PMI (PMBoK), PRINCE2, P2M, IPMA (ICB), AGILE management principles [14].

From the analysis of scientific works, it is clear that at this time the issue of the project approach to risk management of agrarian projects remains out of the question. Particular attention should be paid to the development of tools and methods for project risk management specifically for small and medium-sized businesses in agro-industrial complex.

The aim of this study is to develop convenient methodological tools to be used by small and medium businesses when accomplishing the agroindustrial projects (AIP).

Materials and methods. One of the most important functions of management is the creation of conditions necessary for future successful operation of the enterprise. Therefore, the basic principle and guideline for management should be not maximization of profit, but successful management of risk situations, which in the long run will ensure the highest financial stability of the company.

Risk management system of agro-industrial projects, like any other, must be capable of continuous modification with the use of a set of management methods and quickly adapt to changes in environmental conditions. 
Success of agro-industrial complex projects depends on many factors, one of which is responsible relationship between project manager and risk management.

Project manager can, as a result of the project, improve outcome of the project and completely discredit it, thus completing the project without achieving the goal [6].

Responsibilities of the project manager in relation to risks in agricultural projects:

1. Develop a strategic plan and risk management methods, and submit it for consideration and approval by the board of directors.

2. Implement strategic plans and methodologies after their approval by the board of directors.

3. Ensure the development of manuals on the application of methods, procedures and standards for managing the major risks of agricultural projects.

4. Ensure implementation of control over observance of the established limits of risk.

5. Provide immediate notification of non-compliance with these limits.

6. Ensure that internal auditors analyze and assess the adequacy of control methods and compliance with limits and procedures.

7. Develop and apply management reporting systems adequately reflecting risks.

Risk management standards for project management will be useful to agricultural project managers.

Processes of risk management in different methodologies (standards) of project management are somewhat different [6-10]. Convergence of risk management processes was performed on the basis of the analysis of risk management processes in risk management methodologies of PMI (PMBoK), PRINCE2, P2M, IPMA (ICB), AGILE [14].

This made it possible to develop and propose for application two methods of integrated risk management of projects (short or full) that are used in project management in managing the risks of small and medium-sized businesses in agro-industrial complex.

According to Commercial Code of Ukraine [15], economic entities, depending on the number of employees and incomes from any activity during the year, may belong to small business entities, including microenterprises, medium or large enterprises.

In this case, we consider projects of small and medium business entities - they may be, as individuals, registered in the manner prescribed by law, and individuals entrepreneurs or legal entities - economic entities of any organizational form and forms of ownership in which the average number of employees for the reporting period (calendar year) does not exceed 250 and the annual income from any activity does not exceed an amount equivalent to 50 million euro as determined by the average annual rate of the National Bank of Ukraine.

System analysis, expert and static appraisal of the risk management process applications for AIP were used as research methods in this research.

Results and discussion. Reduced method of integrated risk management of agro-industrial projects, which will help in the limited time and resources, to carry out obligatory procedures for risk management of projects, will be formulated in the form of the following sequence of stages (1-4).

1. Identification of risks.
At this stage, the definition of what risks can affect the project and document their characteristics.

The purpose of this step is to compile an exhaustive list of risks based on those risk situations that can create the ground for increasing opportunities, preventing, aggravating or reducing goals. It is important to identify the risks associated with the lost opportunity. Exhaustive identification is critically important, since the risk that was not identified at this stage will not be included in further analysis.

Incoming data for identification of risks:

- $\quad$ environmental factors of the enterprise;

- $\quad$ assets of the organizational process;

- $\quad$ project content;

- $\quad$ risk management plan;

- $\quad$ project management plan.

You can use such tools and methods as:

- documentation reviews;

- methods of collecting information;

- control analysis;

- $\quad$ assumptions analysis;

- methods of charting;

- $\quad$ expert method.

At the exit we get a risk register.

2. Risk analysis.

This stage involves carrying out both qualitative and quantitative risk analysis.

Qualitative risk analysis is the location of risks by their degree of priority for further analysis or processing by assessing and summing up the probability of their occurrence and impact on the project.

Quantitative risk analysis is a process of quantitative risk analysis for project purposes.

At this stage, consideration is given to the causes and sources of risk, its positive and negative consequences and the probability of occurrence of these consequences. Factors that influence the consequences and probabilities must be determined. The risk is analyzed by identifying the consequences and their likelihood, as well as other accompanying risk characteristics. A risk case can have multiple consequences and affect multiple targets.

Purpose of determining the degree of risk is to make decisions based on the outcomes of risk analysis, namely, what risks need to be treated and their priority in the application of treatment.

Determination of the degree of risk involves comparing the level of risk identified in the risk analysis with the risk criteria defined in the context of establishment. The need for processing is considered on the basis of such a comparison.

3. Development of response plan.

This is the stage of developing ways and developing a plan of action to increase opportunities and reduce the threats to the objectives of the project. Particular attention is paid to the preparation of a plan of countermeasures against risks. The process of choosing a countermeasures against risk is guided by such principles as: choice of alternatives, choice of cost, optimal cost of options.

Risk prevention is divided into two directions [11]:

1. Risk Management Plan:

- $\quad$ risk avoidance - distribution between participants based on contracts, etc.;

- $\quad$ risk reduction - search for a countermeasure;

- distribution of risk - creation of a consortium;

- $\quad$ transfer of risk - transfer to project stakeholders. 


\section{Risk financing:}

- $\quad$ risk transfer - insurance coverage;

- risk retention - a cash sum of risk (escalation, unforeseen costs, insurance reserves) or self-insurance.

It should also be remembered about strategies for responding to positive risks:

- Use strategy is intended to eliminate all uncertainties associated with the risk of the upper level, to ensure that this opportunity arises in various forms.

- $\quad$ Sharing strategy implies the responsibility of the third party that is best placed to take advantage of such an opportunity.

- Strategy of strengthening is intended to increase the size of a favorable opportunity by identifying and maximizing the main sources of positive risks.

The planned risk response operations must be timely, cost-effective in solving the problem, realistic in the context of the project, agreed with all stakeholders, and respond to the seriousness of the risk [16].

4. Risk control.

The purpose of this phase is to monitor the situation during the project, which does not allow for a risky occurrence, verification of the effectiveness of the response plan and its improvement. Unfortunately, not always, not all risks can be foreseen and avoided because the situation in the agro-industrial complex projects, as well as in any other projects, is dynamic, but due to the rapid and effective response it is possible to reduce the devastating risk of the project . For this, ongoing monitoring of tracking identified risks, monitoring of final risks, identifying new risks and evaluating the effectiveness of risk management during the project are carried out.

Schematically reduced method of integrated risk management projects in the agro-industrial complex is shown in Fig.1.

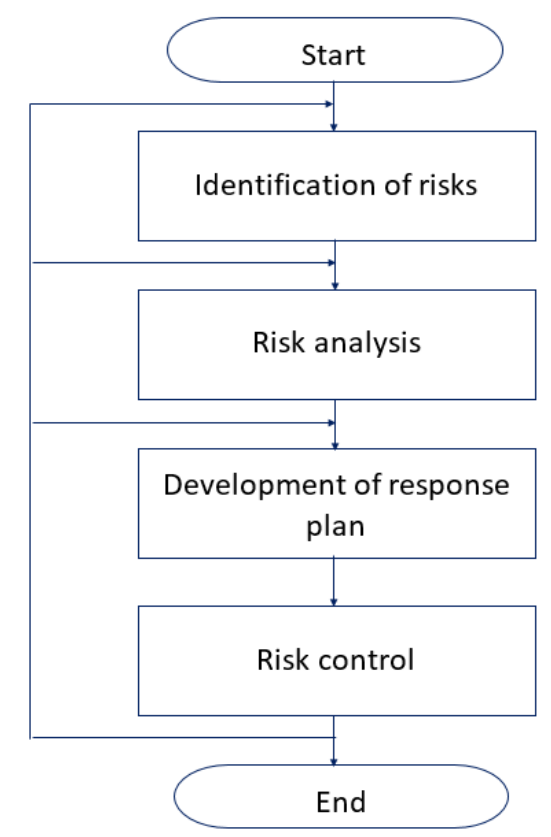

Fig. 1. The reduced method of integrated risk management projects in the agro-industrial complex

The complete risk management project for agro-industrial complex. It is proposed to apply this method to more experienced and ambitious project managers who have more time and resources at their disposal. It consists of the following procedures:

1. Risk Management Planning / Prediction.

At this stage, risk management plan is being developed. This is a document that describes the general approaches to project risk management, their classification, identification and response methods.

2. Identification of risks and environment.

At this stage, the collection of information on the project as a whole (internal and external environment) and, accordingly, compilation of the risk register is carried out.

3. Risk analysis (qualitative and quantitative).

This phase includes: identifying risk events, analyzing the consequences of their occurrence, determining their size and likelihood of occurrence, as well as collecting and processing data on risk aspects.

Risk analysis is divided into two types: qualitative and quantitative.

- Qualitative risk analysis is the process of placing the risks on the level of their priority for further analysis or processing by assessing and summing up the probability of their occurrence and impact on the project.

- Quantitative risk analysis is a process of quantitative risk analysis for project purposes.

4. Development of response plan.

Identification of actions and methods to mitigate the negative consequences of risk events and the use of possible benefits for the project.

With the flow of time and the change of the situation every minute, the importance of conducting the next stage of the algorithm of the full method of risk management of small and medium enterprises of agro-industrial complex is connected. It carries out such procedures as:

5. Renewal of project plans, taking into account the plan of response to risks.

- Permanent assessment of the probability of achieving goals.

- $\quad$ Permanent identification of new risks, reassessment of risks, updating of the response plan.

6. Risk control.

At this stage, verification of effectiveness of response plan and its improvement is carried out.

Planned response to the risk is:

- meet the seriousness of the risk;

- be cost-effective in solving problems;

- be timely;

- be realistic in the context of the project;

- be consistent with all participants.

7. Documentation of risk information for future projects. Improvement of risk identification tools.

At this stage, information on risks is stored, for more successful implementation of future projects.

Such an enterprise database on risk management in each individual project will become an effective basis for managing agro-industrial complex projects, as they are critical, accumulate experience of the latest implemented projects, accumulation of expert knowledge, education and personnel training.

Results of risk management are recorded in the project check-list, which lists all risk events, in such a way that they can be easily and conveniently used in subsequent similar projects. 
In order to map the deviations and fluctuations between the planned and actual project design for each specific task, probability data must be statically grouped and structured.

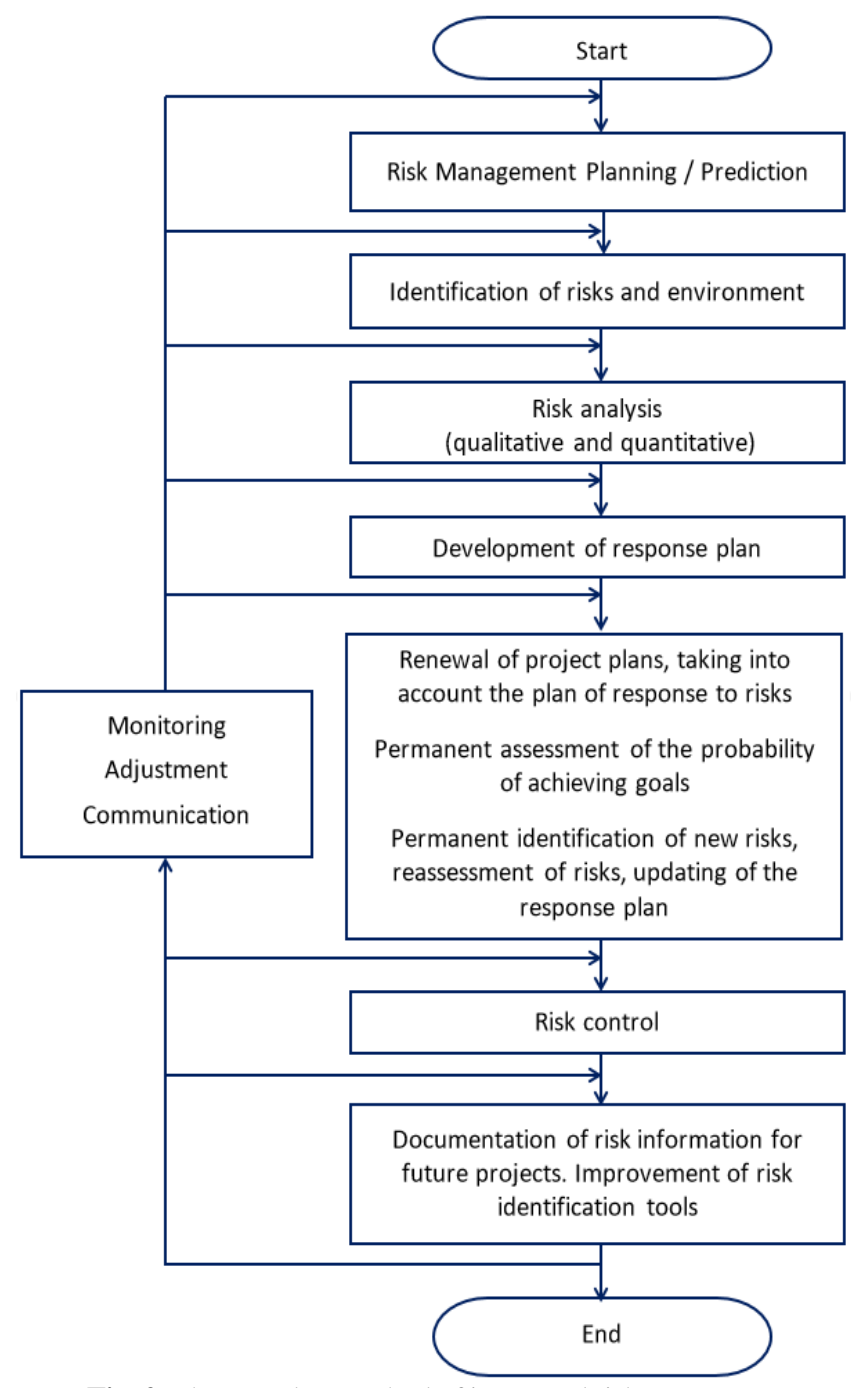

Fig. 2. The complete method of integrated risk management projects in the agro-industrial complex

It is critical to compare incoming data and modeling results using statistical project costing methods without time constraints [11].

Along with collection and organization of knowledge of risk-response, it is critical to prepare a knowledge base on such activities and lessons regarding their implementation and performance.
8. Monitoring, communication and adjustment procedures are carried out in parallel to each stage of risk management.

Monitoring is tracking identified risks, monitoring the final risks, identifying new risks and evaluating the effectiveness of risk management during the project.

Adjustment, in this case, is the correction of risk response plans.

Communications are conducting discussion of project risks within the project team and with stakeholders of the project.

To ensure the completeness and effectiveness of risk management in integrating risk management processes in various project management methodologies (PMBoK, PRINCE2, P2M, IPMA (ICB), AGILE), special attention was paid to the importance of not losing the best features of each methodology [17] . That is why this full management method is unique, and its application will enable the project manager and project team to be sure that they have used and conducted all risk management procedures out of five most authoritative and popular methodologies for project risk management. Using this method will help top management in managing the risks of agribusiness projects, and will increase return on business.

Schematically complete method of risk management projects in the agro-industrial complex is shown in Fig.2.

Conclusions. According to the results of this study, two methods were developed: reduced and complete, as well as description of risk management algorithms for agroindustrial complex projects.

Reduced risk management method for agro-industrial projects can become very popular for use by project managers in managing the risks of agribusiness projects for both small and medium-sized businesses. Significant advantage of this method is clarity, transparency and small number of procedures. This, in turn, should be encouraged, and the main thing is not to deter it from its complexity, small and medium businesses begin to manage risks in their agro-industrial companies.

For more experienced and ambitious project managers who have more time and resources at their disposal, it is proposed to use in their projects a complete risk management method for agro-industrial projects.

In addition, we can conclude that the identified topics are relevant and require further research, and there is a need for the creation of effective, understandable and easy to use risk management tools in agro-industrial projects for small and medium-sized businesses.

\section{ЛІТЕРАТУРА}

1. Денчик О.Р. Аналіз ризиків проектів у агропромисловому комплексі / О.Р. Денчик, Д.І. Бедрій, С.О. Савченко // Вісник ЧДТУ. Серія: Технічні науки. Черкаси, ЧДТУ, 2017. № 1. С. 100-109.

2. Кобилянська О.М. Виробничі ризики сільськогосподарських підприємств: автореф. дис. на здобуття наук. ступеня канд. екон. наук: спец. 08.00.04 "Економіка та управління підприємствами (за видами економічної діяльності)" / О. М. Кобилянська. К., 2011. 20 с.

3. Nguyen, N., Wegener, M., Russell, I., Cameron, D., Coventry, D. \& I Cooper. Risk management strategies by Australian farmers: two casestudies, AFBM Journal, 2007, vol. 4. no. 1 \& 2, pp. 2330 .

5. Hurduzeu, G. The most important agriculture risk. The risk culture / Hurduzeu, G., Huidumac, C. \& Hurduzeu, R. // Proceedings of the 7th International Management Conference "New Management for the New Economy", 7-8 November 2014. Bucharest, Romania: Academy of Economic Studies, 2014. vol. 8 (1), pp. 413-418.

6. A Guide to the Project Management Body of Knowledge (PMBOK® Guide) - Sixth Edition. USA: PMI, 2017. 756 p.

7. Bentley C. PRINCE2: A Practical Handbook - Third Edition. London, UK: Routledge, 2010. p. 322.

8. A Guidebook of Program \& Project Management for Enterprise Innovation. Japan: Project Management Association of Japan (PMAJ), 2017. p. 427. 
9. ICB: IPMA Competence Baseline Version 3.0. Netherlands: IPMA, 2006. $200 \mathrm{p}$.

10. Agile Practice Guide. USA.: PMI, 2017. 210 p.

11. Данченко О.Б. Огляд сучасних методологій управління ризиками в проектах / О.Б. Данченко // Управління проектами та розвиток виробництва: Зб.наук.пр. Луганськ: вид-во СНУ ім. В.Даля, 2014. №1 (49). С. 16-25.

12. Бушуев С. Д. Системная модель механизмов конвергенции в управлении проектами / С. Д. Бушуев, С. И. Неизвестный, Д. А. Харитонов // Управління розвитком складних систем. К.: КНУБА, 2013. № 13. С. 12 - 18.

13. Бушуев С. Д. Механизмы конвергенции методологий управления проектами / С. Д. Бушуев, Н. С. Бушуева, С. И. Неизвестный // Управління розвитком складних систем. К.: КНУБА, 2012. №. 11. С. 5 - 13.

14. Денчик О. Р. Концептуальна модель інтегрованого управління ризиками проектів агропромислового комплексу / О. Р. Денчик // Тези доповідей XIV міжнародної конференції «Управління проектами у розвитку суспільства». Тема: Розвиток компетенцій проектного управління в умовах кризи // Відпов. за вип. С.Д. Бушуев. К.: КНУБА, 2017. С. 84-85.

15. Господарський кодекс України: закон України від 16 січня 2003 р. № 436-IV // Відомості Верховної Ради України, 2013. № 18, № 19-20, № 21-22, Ст. 144.

16. Борисова Н. І. Сучасні методи і засоби управління ризиками в застосуванні до управління проектами альтернативної енергетики / Н. І. Борисова // Вісник ЧДТУ. Серія: Технічні науки. Черкаси: ЧДТУ, 2014. № 2. С. $19-25$.

17. Денчик О.Р. Порівняльний аналіз процесів управління ризиками в різних методологіях управління проектами / О.Р. Денчик, С.О. Паливода // Українські перспективи у світовому розвитку. Матеріали Науково-практичної конференції 04 листопада 2016 року. К.: Університет економіки та права «КРОК», 2016. С. 338-340.

\section{REFERENCES}

1. Denchyk O. R., Bedryj D. I. \& Savchenko S. O. Analiz ry zy'kiv proektiv $v$ agropromy`slovomu kompleksi [Project risks analysis in agricultural sphere]. Visnyk Cherkas'koho derzhavnoho tekhnolohichnoho universytetu. Seriya: Tekhnichni nauky [Bulletin of Cherkasy State Technological University. Series: Engineering]. Cherkasy, 2017, no. 1, pp. 100-109.

2. Kobylyans'ka O. M. Vyrobnychi ryzyky sil's'kohospodars'kykh pidpryyemstv. Avtoreferat Dys. [Production risks Agricultural Enterprises: Author's abstract], Kyiv, 2011, 20 p.

11. Danchenko O. B. Ohlyad suchasnykh metodolohiy upravlinnya ryzykamy $v$ proektakh [Overview of modern risk management methodologies in projects]. Upravlinnya proektamy ta rozvytok vyrobnytstva: $z b$. nauk. pr. [Project management and development of production: Collection of Scientific Publications], 2014, no. 1 (49), pp. 16-25.

12. Bushuev S. D., Neyzvestnyi S. Y., Kharytonov D. A. Sistemnaya model mehanizmov konvergentsii v upravlenii proektami [System model of convergence mechanisms in project management]. Upravlinnya rozvy'tkom skladny'x sy'stem [Management of development of complex systems], 2013, no. 13, pp. 12-18.

13. Bushuev S. D., Bushueva N. S., Neyzvestnyi S. Y. Mehanizmyi konvergentsii metodologiy upravleniya proektami [Convergence mechanisms of project management methodologies]. Upravlinnya rozvy'tkom skladny'x sy'stem [Management of development of complex systems], 2012, no. 11, pp. 5-13.

14. Denchyk O. R. Konceptual'na model integrovanogo upravlinnya ry`zy`kamy` proektiv agropromy`slovogo kompleksu [Conceptual model of integrated risk management projects in the agro-industrial complex]. Tezy XIV mizhnarodnoyi konferenciyi "Upravlinnya proektamy` u rozvy`tku suspil'stva". Tema: Rozvy`tok kompetencij proektnogo upravlinnya v umovax kry`zy' [Proceeding of the $14^{\text {th }}$ International Conference "Project management in the development of society". Subject: Development of project management competencies in a crisis], Kyiv, 2017, pp. $84-85$

15. Gospodars`ky`j kodeks Ukrayiny: zakon Ukrayiny` vid 16 sichnya 2003 r. no. 436-IV [Economic Code of Ukraine: Law of Ukraine of January 16, 2003 No. 436-IV]. Vidomosti Verxovnoyi Rady`Ukrayiny`[ Vidomosti Verxovnoyi Rady`Ukrayiny], 2013, № 18, № 19-20, № 21-22, Art. 144.

16. Bory`sova N. I. Suchasni metody` $i$ zasoby` upravlinnya ry`zy'kamy` $v$ zastosuvanni do upravlinnya proektamy al'ternaty`vnoyi energety'ky`omu kompleksi [Modern methods and tools for managing risks in application to managing alternative energy projects]. Visnyk Cherkas'koho derzhavnoho tekhnolohichnoho universytetu. Seriya: Tekhnichni nauky [Bulletin of Cherkasy State Technological University. Series: Engineering], 2014, no. 2, pp. 19-25.

17. Denchyk O. R. \& Palyvoda S. O. Porivnyal ny j analiz procesiv upravlinnya ry`zy`kamy` $v$ rizny`x metodologiyax upravlinnya proektamy' [Comparative analysis of risk management processes in various project management methodologies]. Materialy Naukovo-praktychnoyi konferentsiyi "Ukrayins'ki perspektyvy u svitovomu rozvytku" [Proceeding of the Scientific and Practical Conference "Ukrainian perspectives in world development"], Kyiv, 2016, pp. 338-340. 